\title{
THE CHANGES OF MARKERS OF ENERGY HOMEOSTASIS, ADIPOKINES, CARBOHYDRATE METABOLISM IN PATIENTS WITH ACUTE MYOCARDIAL INFARCTION ACCOMPANIED BY OBESITY
}

\author{
Koteliukh M. \\ Kharkiv National Medical University, Ukraine \\ https://doi.org/10.35339/ic.7.4.168-173
}

\begin{abstract}
Background. Obesity is associated with the changes in energy homeostasis (irisin and adipokine) and the adipokine system (FABP 4 and CTRP 3 ) and the impact on the development and course of cardiovascular diseases. The purpose of the study was to investigate the time course of markers of energy homeostasis, adipokines and carbohydrate metabolism and their relationship in patients with acute myocardial infarction with the presence and absence of comorbid pathology. Materials and methods. The study involved 189 patients with acute myocardial infarction with and without obesity. The control group included 20 healthy subjects. Adropin, irisin, FABP 4, CTRP 3, insulin were determined by enzymelinked immunosorbent assay. Results of the study. All groups of patients during the observation were found to have a decrease in the levels of glucose, insulin, HOMA index $(p<0.05)$. An increase in adropin, irisin and CTRP 3 and a decrease in FABP 4 in all groups of patients compared with patients by $1-2$ days $(p<0.05)$ were determined on day 10 . The relationship between carbohydrate metabolism and adropin, irisin, FABP 4, CTRP 3 in all groups of patients on days 1-2 was revealed. Conclusions. Our findings indicate that the markers of energy homeostasis and adipokine system influence the state of carbohydrate metabolism in patients with acute myocardial infarction with concomitant obesity was determined.

Key words: adipokines, carbohydrate metabolism, acute myocardial infarction, energy homeostasis, obesity.
\end{abstract}

\section{Introduction}

Coronary artery disease is known to be one of the most common cardiovascular diseases in Western Europe and Ukraine [2]. Obesity is a significant factor that causes the adverse course of acute myocardial infarction (AMI) [19]. It is believed that pathological obesity is a chronic systemic inflammatory process $[11 ; 17]$. Many adipokines and peptides, which are involved in glucose and lipid metabolism, formation of insulin resistance (IR), and inflammatory reactions, are synthesized in the adipose tissue. The role of adropin, irisin, fatty acid binding protein 4 (FABP 4) and C1q/TNF-Related Protein (CTRP 3) in development of acute myocardial infarction in patients with or without obesity has not been

Corresponding Author:

Mariia Koteliukh, MD, PhD, assistant

of the Department of Internal Medicine \#2,

Kharkiv National Medical University, Kharkiv, Ukraine.

E-mail:koteliukh@gmail.com studies in detail [5-9]. Adropine and irisin affect homeostasis of glucose and lipids, play an important role in prevention of insulin resistance, dyslipidemia associated with obesity $[1 ; 3 ; 4 ; 10]$. Recent studies have found a close relationship between the markers of energy homeostasis and the adipokine system and many major chronic diseases, including obesity, type 2 diabetes, and cardiovascular disease [12-16;18]. Thus, further study of energy homeostasis and adipokines may reveal new diagnostic aspects of the treatment of CVD-associated obesity.

\section{Purpose, subjects and methods}

2.1. The purpose of the work was to study the time course of energy homeostasis (adropin and irisin), adipokine system (FABP 4 and CTRP 3 ), carbohydrate metabolism in development of acute myocardial infarction, as well as to investigate the relationship between the components of energy homeostasis, adipokines and carbohydrate metabolism in patients with and without obesity. 


\subsection{Subjects and Methods}

The study was performed within the period of 01 September 2018 and 31 December 2019. The study involved 189 patients, including 30 women (15.9\%) and 159 men (84.1\%), who were undergoing in-patient treatment in the infarction department of Kharkiv City Clinical Hospital No. 27 (clinical center of the academe member L.T. Malaya Department of Internal Medicine No. 2, Clinical Immunology and Allergology of Kharkiv National Medical University of Ministry of Health of Ukraine), at the Department of Resuscitation and Intensive Care of the State Institution L.T. Malaya National Institute of Therapy of the National Academy of Medical Sciences of Ukraine and in cardiology department No. 1 of Kharkiv Clinical Railway Hospital of the Health Care Center of the Public Joint Stock Company Ukrainian Railways. All patients were divided into the following groups: group 1 included 69 overweight patients (OW) (including 58 men, 11 women from 40 to 70 years), group 2 consisted of 60 patients with AMI with concomitant obesity (among them 46 men, 14 women from 42 to 70 years). The comparison group consisted of 60 patients with AMI without obesity (55 men, 5 women from 40 to 70 years). The control group included 20 healthy subjects ( 7 men and 14 women, aged 47 to 60 years).

The diagnosis of AMI was defined made in accordance with the Order of the Ministry of Health No.455 of 02.07.2014 "Unified clinical protocol of emergency, primary, secondary (specialized) and tertiary (highly specialized) medical care and medical rehabilitation of patients with acute coronary syndrome with ST wave elevation based on clinical, electrocardiographic and biochemical criteria". Obesity was identified according to the classification based on the body mass index (BMI), developed by the US National Institutes of Health and approved by the WHO. The treatment of obesity was carried out under the European recommendations of 2018 [19].

Exclusion criteria were type 2 diabetes, autoimmune diseases, diffuse connective tissue diseases, pituitary and hypothalamic diseases, thyroid disease, symptomatic hypertension, heart valve disorders, CHF IV FC to myocardial infarction, chronic obstructive pulmonary disease, marked renal impairment, severe anemia, cancer.

Adropin, irisin, FABP 4, CTRP 3 contents were evaluated by enzyme-linked immunosorbent assay using a set of reagents Human adropin (AD) (Elabscience, Houston, USA), Human Fibronectin type III domain- containing protein 5
(FNDC5) (Elabscience, USA), Human Fatty acid Binding Protein 4 (FABP 4) (Elabscience, USA), Human CTRP 3 (Aviscera Bioscience Inc, Santa Clara, USA) according to the specified instructions for analysis. Insulin content was determined by enzyme-linked immunosorbent assay using the Human Insulin Reagent Kit (Monobind Inc, Lake Forest, USA). Glucose levels were examined by the glucoxidant method in capillary blood on an empty stomach. Assessment of insulin resistance (IR) was performed by calculating the HOMA index.

Mathematical computer processing of research results was performed using "IBM SPPS Statistics 27.0" (IBM Inc., USA, license No. L-CZAA-BKKMKE) and Microsoft Office Excel software. The mean value $(\mathrm{M})$, standard deviation, probability and significance level (p) were calculated. For all groups of patients, the indicators did not have a normal distribution according to the Shapiro-Wilk test. Independent comparisons were performed using the nonparametric MannWhitney U-test. Differences were considered significant at a level of statistical significance $p<0.05$. To assess the relationships between the parameters, we used the method of correlation analysis with calculations of Spearman's correlation coefficients (with a distribution that differs from normal) [20].

The design of the study was approved by the Ethics Commission of Kharkiv National Medical University (Minutes No.2 of 2 April 2018). All patients who participated in the study signed a voluntary informed consent to participate.

\section{Conflict of interests}

This study was supported by Kharkiv National Medical University (No. 0120U102025; valid term 2020-2022). The funder had no role in the study design, data collection and analysis, decision to publish and preparation of the paper.

\section{Results and discussion}

The results of the study of carbohydrate metabolism on days $1-2$ in patients with acute myocardial infarction with and without obesity are presented in Fig. 1. The levels of glucose, insulin, IR HOMA index in patients with overweight (OW) and obesity on day 10 did not have a significant difference when compared with the patients with AMI without OW and obesity $(\mathrm{p}<0.05)$. The patients with AMI, depending on the presence and absence of OW and obesity, were shown to have a decrease in glucose, insulin, IR HOMA index in the time course of observation $(\mathrm{p}<0.05)$ (Table 1).

The results of the study of markers of energy homeostasis and adipokines in patients with AMI 


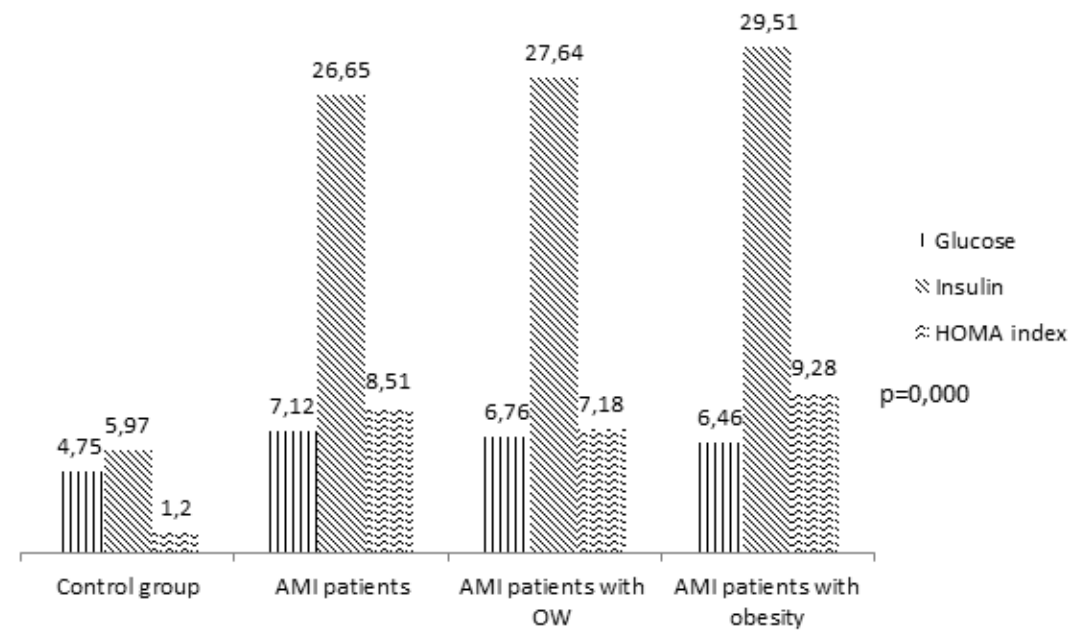

Fig. 1. Carbohydrate metabolism in patients with acute myocardial infarction depending with or without obesity on days 1-2 of observation

Table 1

Determining the time course of carbohydrate metabolism in patients with AMI depending on the presence and absence of obesity

\begin{tabular}{|c|c|c|c|c|c|}
\hline \multirow[t]{2}{*}{ Indicators } & $\begin{array}{c}\text { Control group } \\
n=20\end{array}$ & $\begin{array}{c}\text { AMI patients } \\
n=60\end{array}$ & $\begin{array}{c}\text { AMI patients } \\
\text { with OW } \\
n=69\end{array}$ & $\begin{array}{c}\text { AMI patients } \\
\text { with obesity } \\
n=60\end{array}$ & \multirow[t]{2}{*}{$\begin{array}{l}\text { Probability } \\
\text { (p) }\end{array}$} \\
\hline & 0 & 1 & 2 & 3 & \\
\hline $\begin{array}{l}\text { Glucose } \\
10^{\text {th }} \text { day, } \mathrm{mmol} / / \mathrm{l}\end{array}$ & $4.75 \pm 0.08$ & $5.57 \pm 0.08$ & $5.67 \pm 0.08$ & $5.60 \pm 0.11$ & $\begin{array}{l}\mathrm{p}_{1-2}=0.307 \\
\mathrm{p}_{1-3}=0.726 \\
\mathrm{p}_{1-1}=0.000 \\
\mathrm{p}_{2-2}=0.000 \\
\mathrm{p}_{3-3}=0.012\end{array}$ \\
\hline $\begin{array}{l}\text { Insulin } 10^{\text {th }} \text { day, } \\
\mathrm{mcU} / \mathrm{ml}\end{array}$ & $5.97 \pm 0.43$ & $17.17 \pm 0.74$ & $17.43 \pm 0.80$ & $18.07 \pm 0.70$ & $\begin{array}{l}\mathrm{p}_{1-2}=0.869 \\
\mathrm{p}_{1-3}=0.416 \\
\mathrm{p}_{1-1}=0.000 \\
\mathrm{p}_{2-2}=0.000 \\
\mathrm{p}_{3-3}=0.000\end{array}$ \\
\hline $\begin{array}{l}\text { HOMA index } \\
10^{\text {th }} \text { day }\end{array}$ & $1.20 \pm 0.08$ & $4.24 \pm 0.19$ & $4.40 \pm 0.21$ & $4.50 \pm 0.19$ & $\begin{array}{l}\mathrm{p}_{1-2}=0.996 \\
\mathrm{p}_{1-3}=0.312 \\
\mathrm{p}_{1-1}=0.000 \\
\mathrm{P}_{2-2}=0.000 \\
\mathrm{P}_{3-3}=0.000\end{array}$ \\
\hline
\end{tabular}

Note. $\mathrm{n}$ - the number of examined subjects, $\mathrm{M} \pm \mathrm{m}$ - arithmetic mean \pm standard deviation, AMI - acute myocardial infarction, OW - overweight.

depending on the presence and absence of obesity within 1-2 days of observation are presented in the Fig. 2. The content of adropin on day 10 was lower in patients with AMI with OW compared with the patients with AMI on day 10, but no significant difference was found $(\mathrm{p}=0.085)$. The level of adropin on day 10 was lower by $11.13 \%$ in obese AMI patients compared with AMI patients without the signs of OW and obesity on day $10(p=0.000)$. An increase in adropin on day 10 was found in patients with AMI with obesity by $29.56 \%$, AMI with OW by $21.88 \%$ and AMI without signs of OW and obesity by $24.76 \%$ compared with patients on days $1-2(p=0.000)$.
The level of irisin on day 10 was significantly lower in patients with AMI with OW by $9.94 \%$ $(\mathrm{p}=0.026)$, by $27.56 \%$ with obesity $(\mathrm{p}=0.000)$ when compared with the patients with AMI. There was a significant increase in the level of irisin for 10 days in patients with AMI with OW by $47.12 \%$, by $33.73 \%$ of AMI with obesity, by $40.54 \%$ with AMI when compared with patients with AMI with or without OW and obesity on days 1-2 $(\mathrm{p}=0.000)$ (Table 2).

The studies $[1 ; 12]$ show that adropin has a significant effect on glucose and lipid homeostasis and may play an important role in prevention of insulin resistance, impaired glucose tolerance, and 


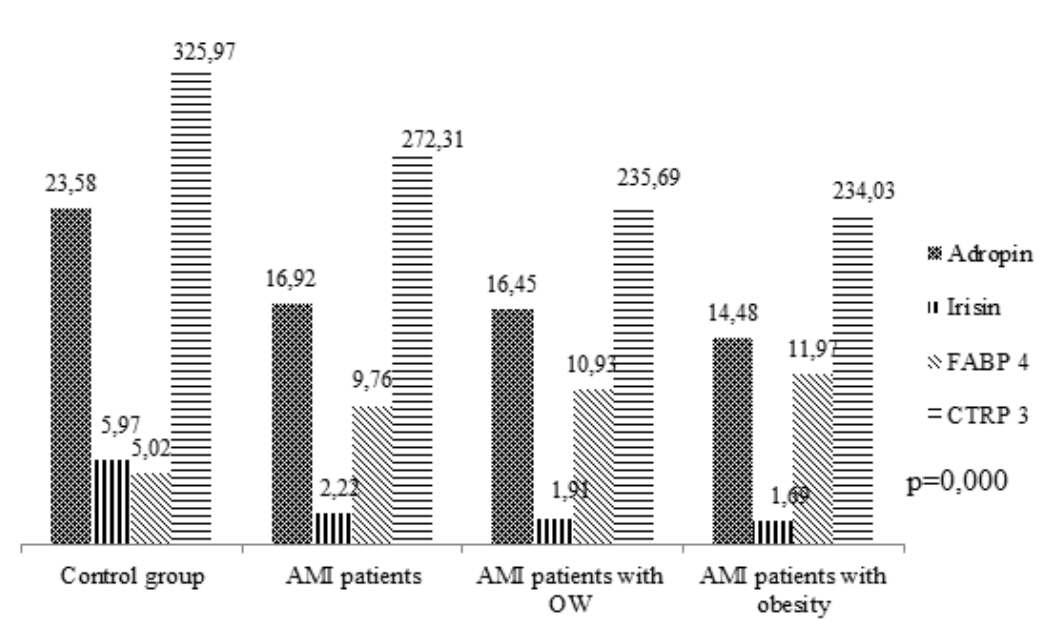

Fig. 2. The markers of energy homeostasis and adipokines in patients with AMI with or without obesity on days 1-2 of observation

The changes in the markers of energy homeostasis and adipokines

Table 2 in patients with AMI with or without obesity

\begin{tabular}{|c|c|c|c|c|c|}
\hline \multirow[t]{2}{*}{ Indices } & $\begin{array}{c}\text { Control group } \\
n=20\end{array}$ & $\begin{array}{c}\text { AMI patients } \\
n=60\end{array}$ & $\begin{array}{c}\text { AMI patients } \\
\text { with OW } \\
n=69\end{array}$ & $\begin{array}{c}\text { AMI patients } \\
\text { with obesity } \\
n=60\end{array}$ & \multirow[t]{2}{*}{$\begin{array}{l}\text { Probability } \\
\text { (p) }\end{array}$} \\
\hline & 0 & 1 & 2 & 3 & \\
\hline $\begin{array}{l}\text { Adropin } \\
10^{\text {th }} \text { day, } \mathrm{pg} / \mathrm{ml}\end{array}$ & $23.58 \pm 0.57$ & $21.11 \pm 0.31$ & $20.05 \pm 0.35$ & $18.76 \pm 0.50$ & $\begin{array}{l}\mathrm{p}_{12}=0.085 \\
\mathrm{p}_{13}=0.000 \\
\mathrm{p}_{11}=0.000 \\
\mathrm{p}_{22}=0.000 \\
\mathrm{p}_{33}=0.000\end{array}$ \\
\hline $\begin{array}{l}\text { Irisin } \\
10^{\text {th }} \text { day, } \mathrm{ng} / \mathrm{ml}\end{array}$ & $5.97 \pm 0.47$ & $3.12 \pm 0.11$ & $2.81 \pm 0.11$ & $2.26 \pm 0.06$ & $\begin{array}{l}\mathrm{p}_{12}=0.026 \\
\mathrm{p}_{13}=0.000 \\
\mathrm{p}_{11}=0.000 \\
\mathrm{p}_{22}=0.000 \\
\mathrm{p}_{33}=0.000\end{array}$ \\
\hline $\begin{array}{l}\text { FABP } \\
410^{\text {th }} \text { day, ng/ml }\end{array}$ & $5.02 \pm 0.43$ & $7.72 \pm 0.21$ & $8.40 \pm 0.28$ & $9.52 \pm 0.49$ & $\begin{array}{l}\mathrm{p}_{12}=0.326 \\
\mathrm{p}_{13}=0.009 \\
\mathrm{p}_{11}=0.000 \\
\mathrm{p}_{22}=0.000 \\
\mathrm{p}_{33}=0.000\end{array}$ \\
\hline $\begin{array}{l}\text { CTRP } \\
310^{\text {th }} \text { day, } \mathrm{ng} / \mathrm{ml}\end{array}$ & $325.97 \pm 9.44$ & $292.57 \pm 2.88$ & $270.68 \pm 4.48$ & $265.31 \pm 5.78$ & $\begin{array}{l}\mathrm{p}_{12}=0.001 \\
\mathrm{p}_{13}=0.002 \\
\mathrm{p}_{11}=0.000 \\
\mathrm{p}_{22}=0.000 \\
\mathrm{p}_{33}=0.000\end{array}$ \\
\hline
\end{tabular}

Note. $\mathrm{n}$ - the number of examined subjects, $\mathrm{M} \pm \mathrm{m}$ - arithmetic mean \pm standard deviation, AMI - acute myocardial infarction, OW - overweight.

dyslipidemia associated with type 2 diabetes or obesity. The researchers found a significant inverse correlation between adropin and glucose levels, body mass index (BMI) and triglycerides in patients with AMI. The study found that high concentrations of irisin were associated with greater reductions in blood glucose and insulinemia after weight loss in obese subjects. Studies showed a positive correlation between irisin and BMI, glucose, triglycerides [3; 4; 13].
The content ofFABP 4 on day 10 significantly decreased in patients with AMI with obesity by $23.31 \%$ compared with patients with AMI on the $10^{\text {th }}$ day $(\mathrm{p}<0.05)$. However, no significant difference was found when comparing AMI patients with OW and AMI patients on day 10 $(p=0.326)$. There was a significant decrease in the level of FABP 4 on day 10 in patients with AMI by $20.90 \%$, with OW by $23.14 \%$, by $20.43 \%$ with obesity compared with the patients with AMI 
with or without OW and obesity on days $1-2$ $(p=0.000)$. The researchers $[5 ; 6 ; 8]$ found that FABP4 levels were significantly elevated in obese patients compared to non-obese patients, and serum FABP4 levels were positively correlated with the waist circumference, blood pressure and insulin resistance. According to the results of the studies elevated FABP4 levels were associated with obesity, insulin resistance, type 2 diabetes, hypertension, cardiac dysfunction, and atherosclerosis.

The concentration of CTRP 3 on the $10^{\text {th }}$ day significantly increased in patients with AMI with OW by $7.48 \%$ ( $\mathrm{p}=0.001)$, by $9.32 \%$ with obesity $(p=0.002)$ compared with the patients with AMI on the $10^{\text {th }}$ day. There was a significant increase in the content of CTRP 3 on the $10^{\text {th }}$ day in patients with AMI by $7.44 \%$, with OW by $14.85 \%$, with obesity by $13.37 \%$ when compared with AMI patients with the presence and absence of OW and obesity on days $1-2(\mathrm{p}=0.000)$ (Table 2$)$. The relationship between CTRP 3 and coronary artery disease can be explained by the effect of CTRP 3 on various aspects of atherosclerosis, such as inflammation and metabolic disorders. CTRP3 levels negatively correlated with metabolic risk factors, including waist circumference, triglycerides and glucose levels, and the HOMA index. For CTRP3, the biological function of the metabolic regulator of glucose homeostasis was determined. The study found a significant reduction in CTRP 3 levels in acute coronary syndrome with control subjects [7]. Adjusting cardiovascular risk factors further enhances the relationship between CTRP 3 and coronary artery disease levels. In an experimental study, it was found that the expression of CTRP 3 in adipocytes decreased significantly 1 day after AMI and gradually recovered. Plasma CTRP3 levels decreased significantly after AMI, reaching its lowest level 3 days after AMI. The expression or production of CTRP 3 changes during cardiac reconstruction after AMI [7].

Thus, there are statistically significant disturbances in the regulation of the adipokine response and energy homeostasis in patients with AMI with concomitant obesity.

\section{Conclusions}

1. Decreased concentrations of adropin, irisin, CTRP 3 and increased levels of FABP 4 on days 1-2 in patients with acute myocardial infarction and obesity indicate a probable relationship with carbohydrate metabolism and impaired energy homeostasis and adipokine imbalance.

2. The changes of the indicators revealed the changes in the system of energy homeostasis and adipokine response and demonstrated the effect of irisin, FABP 4, CTRP 3 on development of AMI in obese subjects.

3. The results of the study indicate that the presence of obesity in patients with AMI did not affect the changes in the level of adropin during observation.

\section{Acknowledgements}

The authors thank the patients for their trust and participation in the study. The authors are grateful to the staff of Kharkiv City Clinical Hospital No. 27, the Department of Resuscitation and Intensive Care of the State Institution L.T. Malaya National Institute of Therapy of the National Academy of Medical Sciences of Ukraine, cardiology department No. 1 of Kharkiv Clinical Railway Hospital of the Health Care Center branch of the Public Joint Stock Company Ukrainian Railways for making this research possible.

\section{References}

1. Akcilar, R., Emel Kocak, F., Simsek, H., Akcilar, A., Bayat, Z., Ece, E., Kokdasgil, H. (2016). The effect of adropin on lipid and glucose metabolism in rats with hyperlipidemia. Iranian Journal of Basic Medical Sciences, 19 (3), 245-251.

2. Arhiv derzhavnoyi statistiki Ukrayini. (2020). [Archive of State Statistics of Ukraine]. Retrieved from http://www.ukrstat.gov.ua/operativ/operativ2020/ds/kpops/kpops_u/arh_kpops 2020_u.html

3. Aronis, K.N., Moreno, M., Polyzos, S.A., Moreno-Navarrete, J.M., Ricart, W., Delgado, E., ... Mantzoros, C.S. (2015). Circulating irisin levels and coronary heart disease: association with future acute coronary syndrome and major adverse cardiovascular events. Int J Obes (Lond), 39, 156-161.

4. Aydin, S. (2014). Three new players in energy regulation: preptin, adropin and irisin Peptides, 56, 94-110. doi: 10.1016/j.peptides.2014.03.021.

5. Fisher, R.M., Eriksson, P., Hoffstedt, J., Hamsten, A., Arner, P. (2000). Fatty acid binding proteins in different human adipose tissue depots: Relationships to serum insulin concentrations. Atherosclerosis, 151 (1). doi: https://doi.org/10.1016/S0021-9150(00)80359-7

6. Furuhashi, M. (2019). Fatty acid-binding protein 4 in cardiovascular and metabolic diseases. J Atherosclerosis Thromb, 26, 216-232. doi.org/10.5551/jal.48710 
7. Hofmann, C., Chen, N., Obermeier, F., Paul, G., Buchler, C., Kopp, A., ... Schaffler, A. (2011). C1q/TNF-related protein-3 (CTRP-3) is secreted by visceral adipose tissue and exerts antiinflammatory and antifibrotic effects in primary human colonic fibroblasts. Inflammatory Bowel Diseases, 17 (12), 2462-2471.

8. Ishimura, S., Furuhashi, M., Watanabe, Y., Hoshina, K., Fuseya, T., Mita, T., ... Miura, T. (2013). Circulating levels of fatty acid-binding protein family and metabolic phenotype in the general population. PLoS One, 8 (11), 813-18.

9. Iso T., Maeda K., Hanaoka H., Suga T., Goto K., Syamsunarno Mas Rizky A.A, .. Kurabayashi M. (2013). Capillary endothelial fatty acid binding proteins 4 and 5 play a critical role in fatty acid uptake in heart and skeletal muscle. Arterioscler Thromb Vasc Biol, 2549-2557. doi: 10.1161/ATVBAHA.113.301588

10. Jasaszwili, M, Billert, M, Strowski, MZ., Nowak, K.W., Skrzypski, M. (2020). Adropin as a fatburning hormone with multiple functions-review of a decade of research. Molecules, 25 (3), 549. doi: 10.3390/molecules25030549.

11. Koksharova, E.O., Majorov, A.Yu., Shestakova, M.V., Dedov, I.I. (2014). Metabolicheskie osobennosti i terapevticheskij potencial buroj i "bezhevoj" zhirovoj tkani [Metabolic characteristics and therapeutic potential of brown and "beige" adipose tissue]. Saharnyj diabet, 4, 5-15.

12. Kumar, K.G., Trevaskis, J.L., Lam, D.D., Sutton G.M., Koza R.A., Chouljenko V.N., ... Butler A.A. (2008). Identification of adropin as a secreted factor linking dietary macronutrient intake with energy homeostasis and lipid metabolism. Cell Metab, 8, 168-481. doi: 10.1016/j.cmet.2008.10.011

13. Oelmann S., Nauck M., Volzke H., Bahls M., Friedrich N. (2016). Circulating irisin concentrations are associated with a favourable lipid profile in the general population. Plos one. https://doi.org/10.1371/ journal.pone.0154319

14. Rajala, M.W., Scherer, P.E. (2003). Minireview: the adipocyte-at the crossroads of energy homeostasis, inflammation, and atherosclerosis. Endocrinology, 144 (9), 3765-3773.

15. Sato K., Yamashita T., Shirai R., Yamashita T., Shibata K. (2018). Adropin contributes to antiatherosclerosis by suppressing monocyte-endothelial cell adhesion and smooth muscle cell proliferation. International journal of molecular sciences, 19 (5), 1293.

16. Scherer P.E. (2006). Adipose tissue: from lipid storage compartment to endocrine organ. Diabetes, 55 (6), 1537-1545.

17. Vavilova, T.P., Pleten, A.P., Miheev, R.K. (2017). Biologicheskaya rol adipokinov kak markerov patologicheskih sostoyanij. [Biological role of adipokines as markers of pathological conditions]. Voprosy pitaniya, 86 (2), 5-13.

18. Wu, L.E., Samocha-Bonet, D., Whitworth, P.T., Fazakerley, D. (2014). Identification of fatty acid binding protein 4 as an adipokine that regulates insulin secretion during obesity. Molecular metabolism, 3 , 465-473.

19. Yumuk, V., Tsigos, C., Fried, M., Schindler, K., Busetto, L., Micic, D., Toplak, H. (2015). European guidelines for obesity management in adults. Obesity facts, 8, 402-424. doi: 10.1159/000442721

20. Zhilcov, I., Semenov, V., Zenkova, S. (2014). Osnovy medicinskoj statistiki. Dizajn biomedicinskih issledovanij: prakticheskoe rukovodstvo [Fundamentals of Medical Statistics. Biomedical Research Design : A Practical Guide]. Vitebsk: VGMU

Received: 13-Sep-2020

Accepted: 02-Dec-2020 